\title{
Denetimli Serbestlik Tedbiri Konulan Madde Kullanıcılarında Depresyon Belirti Düzeyine Göre Bağımlılık Şiddetinin İncelenmesi
}

\author{
Investigation of Addiction Severity of Drug Users Under Probation \\ According to Depressive Symptom Level
}

\author{
Gönül Güvenç Bahadır ${ }^{1}$ (D), Semra Karaca 2(D) \\ 1. Mersin Şehir Araştırma ve Eğitim Hastanesi, Mersin \\ 2. Marmara Üniversitesi Sağlık Bilimleri Fakültesi, Psikiyatri Hemşireliği Anabilim Dalı, İstanbul
}

\section{Abstract}

Objective: The aim of this study was to examine the addiction severity in drug users who were imposed judgment of probation according to depressive symptom level.

Method: The descriptive and cross-sectional research was conducted in the sample of drug users $(\mathrm{N}=330)$, whose follow-up is continuing by the probation office. The data were collected using the Personal Information Form, Beck Depression Inventory (BDI), and the Addiction Profile Index Clinical Form (API-C).

Results: The average age of substance users participating in the study was $28.93 \pm 6.96,97 \%$ were male, $40 \%$ were secondary school graduates, and $59.1 \%$ were single. API-C total/severity score of the participants was 12.32 $\pm 4.02,16.7 \%$ of them had moderate and $31.8 \%$ of them had a high level of addiction severity. According to the BDI cut-off point; API-C total and sub-dimensions scores was statistically significantly higher in substance users who high depressive symptom level.

Conclusion: Half of the substance users who are put on probation have low addiction levels. Addiction severity is also high in substance users with high levels of depressive symptoms. In this context, it may be suggested to focus on preventing addiction and early diagnosis and treatment of depressive problems in individuals with substance abuse.

Keywords: Addiction severity, depressive symptom level, substance users

Öz

Amaç: Bu çalışmada; denetimli serbestlik tedbiri konulan madde kullanıcılarında depresif belirti düzeyine göre bağımlılık şiddetinin incelenmesi amaçlandı.

Yöntem: Kesitsel tipteki araştırma, bir denetimli serbestlik şube müdürlüğünce takip edilen madde kullanıcıları örnekleminde ( $\mathrm{N=330)}$ yapıldı. Veriler Kişisel Bilgi Formu, Beck Depresyon Envanteri (BDE) ve Bağımlılık Profili İndeksi Klinik Formu (BAPi-K) ile toplandı.

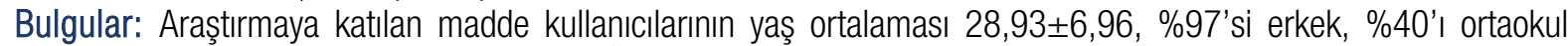
mezunu, \%59,1'i bekardı. Katılımcıların BAPi-K toplam /şiddet puan ortalaması 12,32 $\pm 4,02$ olup, \%16,7'sinde orta ve \%31,8'inde yüksek düzeyde bağımlılık şiddeti olduğu belirlendi. BDE kesme noktasına göre, BAPi-K toplam puanı ve tüm alt boyutlarında depresif belirti düzeyi yüksek olanlar olmayanlara göre istatistiksel olarak anlamlı ölçüde daha yüksek puan aldı.

Sonuç: Denetimli serbestlik tedbiri konan madde kullanıcılarının yarısında bağımlılık şiddeti düşüktür. Depresif belirti düzeyi yüksek olan madde kullanııılarında bağımlıık şiddeti de yüksektir. Bu bağlamda, madde kullanımı olan bireylerde bağımlılı̆ı önlemeye ve depresif sorunların erken tanı ve tedavisine odaklanılması önerilebilir.

Anahtar kelimeler: Madde kullanıcıları, depresif belirti düzeyi, bağımlılık şiddeti 


\section{Giriş}

Madde kullanımı sağıı̆ı olumsuz etkileyen, sıkıkla suç içeren davranışlarla ilişkili olabilen, tüm dünyada yaygınlığı giderek artan bir durumdur. Madde kullanımı ile suç davranışları arasında çift yönlü bir ilişki vardır $(1,2)$. Madde kullanımı, kişiyi suça iten bir araç olabildiği gibi, maddeyi temin etmek amacıyla istemli suç davranışları da görülebilir (2-4). Ülkemizde madde ile ilişkili suçlar, 26 Eylül 2004 tarihli ve 5237 sayılı Türk Ceza Kanununun 191. maddesinde "Kullanmak için uyuşturucu veya uyarıcı madde satın alan, kabul eden veya bulunduran kişi, bir yıldan iki yıla kadar hapis cezası ile cezalandırılır" şeklinde belirtilir. Madde kullanıcıları bağımlı olmasalar da suç davranışları nedeniyle denetimli serbestlik (DS) sitemine dahil olabilmektedir. Ülkemizde 2005'te kurulan DS sistemi ile maddeyle ilișkili suçlardan hüküm giymiş bireylerin suç işlemesine neden olan davranışlarının rehabilite edilmesi, tekrar suç işlemelerinin önlenmesi ve mağdurların uğradıkları zararın giderilmesi hedeflenir (1).

Madde kullanımı tek başına bir hastalık olmasa da psikolojik ve fiziksel olarak bağımlılı̆a yol açması, öz denetimi zayıflatarak sosyal yaşamda kabul edilmeyen davranışlara yol açması nedeniyle madde kullanan bireyler toplumsal ayrımclığa ve dışlanmaya maruz kalabilmektedir (5). Madde kullanan birey, suça karışmış ve hüküm giymişse daha fazla ayrımclığa maruz kalacağı, bu durumun pek çok açıdan bireylerin yaşamını olumsuz etkileyeceği ve depresif duygulanımla ilişkili olabileceği söylenebilir.

Madde kullanımında en önemli sorunlardan biri bağımlılıktır. Madde kullananlarda ortaya çıkabilecek bağımlılığın şiddetini belirlemek, bağımlık gelişmişse bireyin mevcut sorunlarını değerlendirmek; sağlık hizmetleri sunumunda öncelik verilecek alanları belirlemek acısından önem taşır. Madde kullanımı olan kişide bağımlıık tanı ölçütlerinin sayısı, kullanılan maddenin cinsi ve dozu, madde kullanıyor olmanın kişisel ve sosyal yaşama etkisi, madde kullanımına karşı duyulan isteğin yüksekliği gibi değişkenlerin her biri bağımlılık şiddet göstergeleri olarak kabul edilebilir. Bağımlılık şiddeti yüksek olan bireylerde daha yoğun ve uzun süreli tedavinin uygulanması gereklidir (6).

Madde kullanımına eşlik eden ruhsal sorunlar (psikiyatrik komorbidite), hastaların tedaviye uyumunu bozar ve relaps riskini artırır. Bu nedenle, komorbiditelerin belirlenmesi ve tedavi edilmesi önem taşır (7). Literatürde madde kullanımı ile depresif bozuklukların ilişkili olduğu bildirilmiştir (8). Öner ve arkadaşları (9) bağımlı grubunda yaşam boyu majör depresyon ek tanı sıkıı̆ını \%35 olarak saptamıştır. Depresyon madde bağımlıı̆ında tedavinin sonuçlarını olumsuz etkilemekte, yeti yitimini artırmakta ve kaymalarla ilişkili olabilmektedir (10). Yapılan bir çalışmada; bağımlı grubun sağıklı kontrollere göre daha şiddetli depresyon bildirdikleri bulunmuştur (11). Lee ve Yen (12), bireylerin madde kullanımından bekledikleri olumlu duygusal sonuçların (acıdan kaçınma, zevk alma vb) depresyon ve madde kullanımı arasındaki ilişkiye aracılık ettiğini belirlemiştir. Bildiğimiz kadarıyla DS tedbiri konulan madde kullanıcılarında bağımlıık şiddeti ve depresif belirti düzeyini birlikte ele alan çalışma bulunmamaktadır. Bu araştırma DS tedbiri konulan madde kullanıcılarında bağımlılık şiddetinin belirlenmesi ve depresif belirti düzeyine göre bağımlıık şiddetinin değerlendirilmesi amacıyla yapıımıştır.

Bu araştırmada; DS tedbiri konulan madde kullanıcılarında bağımlılık şiddeti ne düzeydedir? DS tedbiri konulan madde kullanıcılarında depresif belirtiler ve bağımlılık şiddeti ilişkili midir? DS tedbiri konulan madde kullanııılarında depresif belirti düzeyine göre bağımlıık şiddeti farkkılaşmakta mıdır? Sorularına yanıt aranmıştır.

\section{Yöntem}

\section{Örneklem}

Kesitsel tipte olan araştırmanın evreni İstanbul Ili Anadolu Yakası Denetimli Serbestlik Müdürlüğü'nde takip edilen, DS tedbiri konulan 18-65 yaş grubu madde kullanıcılarıdır ( $N=7200)$. Örneklem büyüklüğü; bir değer bakımından popülasyonun aritmetik ortalamasını belli bir hata payı içerisinde tahmin etmek için 
gerekli örneklem sayısını hesaplamak için kullanılan formül uygulanarak 325 kişi olarak belirlendi. Araştırma kapsamında 347 madde kullanıcısına ulaşıldı, araştırmaya alınma kriterlerini karşılamayanlar (12 kişide ek psikiyatrik tanı mevcuttu ve 5 kişi veri toplama formlarını eksik/hatalı doldurdu) dışlanarak, 330 madde kullanıcısına ait veri seti analize dahil edildi.

\section{İşlem}

Araştırmanın etik kurul izni bir devlet üniversitesinin sağlık bilimleri enstitüsü etik kurulundan (28.03.20167), kurum izni TC Adalet Bakanlığı Ceza ve Tevkifevleri Genel Müdürlüğünden (29.06.2016-8834) alındı. Ayrıca araştırma bittikten sonra bu makalenin yayınlanabilmesi için de TC Adalet Bakanlığı Ceza ve Tevkifevleri Genel Müdürlüğünden (08.03.2021- B.M.2016/8334) izin alındı. Araştırma öncesi madde kullanıcılarına araştırmanın amacı anlatılı, kişisel bilgilerin gizli kalacağı, araştırma dışında herhangi bir yerde kullanılmayacağı ve çalışmaya katılma durumlarının DS nedeniyle içinde bulundukları mahkeme süreçlerini etkilemeyeceği açıklandı. Tüm katılımcılardan aydınlatımış onam formu ile yazılı onam alındı. DS şube müdürlüğü, madde kullanıcılarını makalenin birinci yazarının da çalıştığı kurum olan bir ruh sağlığı ve hastalıkları hastanesinin alkol madde bağımlılığ merkezi DS polikliniğine yönlendirmekte ve burada uzman hekim psikiyatrik değerlendirme yapmaktadır. Bu poliklinikte ayrıca uyum değerlendirmeleri yapılmakta, gerektiğinde medikal tedavi uygulanabilmektedir. Araştırmada örneklem seçme yöntemi kullanılmamış, araşıırmanın yapııdığı tarihlerde DS şube müdürlüğünde takipli olan, dahil edilme kriterlerini karşılayan ve araştırmaya kayılmayı kabul eden madde kullanıcıları örnekleme alınmıştır.

Araştırmanın verileri makalenin birinci yazarı olan alkol ve madde bağımlı̆̆ı tedavi merkezi hemşiresi tarafından yarı yapılandırımış görüşmelerle, 01.07.2016- 01.10.2017 tarihleri arasında toplanmıştır. Araştırmaya alınma kriterleri; 18 yaş altı ve 65 yaş üstü olmama, iletişimsel bir engeli olmama, okuma yazma bilme ve çalışmaya katımak için gönüllü olmadır. Bu araştırmadan çıkarılma kriterleri ise bağımlıık şiddetini etkileyebileceği için madde kullanıcısının tanılanmış ek bir psikiyatrik tanısının olması örneğin; psikotik bir bozukluk, majör depresyon, obsesif kompülsif bozukluk gibi ve veri toplama formlarının eksik/hatalı doldurulmuş olmasıdır.

\section{Veri Toplama Araçları}

Araştırmanın verileri; Kişisel Bilgi Formu, Beck Depresyon Envanteri (BDE) ve Bağımlıık Profili İndeksi Klinik Formu (BAPi-K) ile toplanmıştır.

\section{Kişisel Bilgi Formu}

Kişisel bilgi formu; yaş, cinsiyet, medeni durum, çalışma ve gelir durumu, cezaevi yaşantısı olup olmadığına iliş̧kin sosyodemografik değişkenleri ve maddeye başlama nedeni, ailede ve çocukların yanında madde kullanımı, madde kullanımıyla ilişkili sorunlar, madde kullanımı nedeniyle ayrımclığa uğrama gibi madde kullanımı ile ilişkili özellikleri sorgulayan 14 çoktan seçmeli sorudan oluşan formdur.

\section{Beck Depresyon Envanteri (BDE)}

BDE depresyonda görülen, vegetatif, duygusal, bilişsel ve motivasyonel alanda ortaya çıan belirtileri ölçmeye yarayan, 21 maddeden oluşan kendini değerlendirme türü ölçektir. Türkçe geçerlilik güvenirliliği Hisli tarafından yapılmıştır (13). BDE'deki her madde depresyona özgü bir davranışsal örüntüyü belirtmekte ve azdan çoğa doğru giden dört derecelik kendini değerlendirme cümlesini içermektedir. Sıfırdan üçe kadar, depresyonun ciddiyetine göre sıralanmış bu cümleler, depresyonun görünümüne ilişkin olup, etiyolojisine ilişkin herhangi bir kuramı yansıtmamaktadır. BDE'nin kesme noktası 17'dir ve toplam puanın 17'nin üstünde olması depresif belirti düzeyinin yüksek olduğunu gösterir. Hisli (13)'nin çalışmasında iç tutarlılık katsayısı Cronbach's $\alpha$,63 olarak bulunmuştur. Bu çalışma için ölçeğin iç tutarlılık kat sayısı Cronbach's $\alpha, 939$ 'dur.

\section{Bağımllık Profil İndeksi Klinik Formu (BAPi-K)}

Bağımlıık Profil İndeksi (BAPi) bağımlıı̆ı̆ın boyutlarını değerlendiren ve bağımlıık şiddetini ölçen, 37 sorudan ve 5 alt ölçekten oluşan bir ölçektir. Bağımlılık Profil İndeksi Klinik Formu (BAPI-K) ise Bağımlıık 
Profil İndeksine 21 soruluk "ruhsal durum" bölümü eklenerek Ögel ve arkadaşları (14) tarafından geliştirilmiştir. BAPI-K bağımlılık ve bağımlı̆ı̆ı etkileyen ruhsal sorunlar olmak üzere iki ayrı bölümden oluşur ve değerlendirme bu bölümlere göre yapılır. BAPI'den alınan toplam puanın 12-14 arasında olması orta bağımlılık şiddeti, 14 puan puanın üzerinde olması ise yüksek bağımlıık şiddeti olarak kabul edilir. Ögel ve arkadaşları (14)'nın çalışmasında BAPI-K'nın Cronbach $\alpha$ katsayısı ,81 olarak bulunmuştur. Bu çalışmada BAPI alt boyutları için Cronbach a katsayıları; madde kullanım özellikleri ,700, maddeyi bırakma motivasyonu ,841, bağımlıık tanı ölçütleri ,902, bağımlıı̆̆ın yaşama etkileri ,928, madde kullanmaya duyulan şiddetli istek ,865'tir. BAPi-K için iç tutarlılık kat sayıları ruhsal alt boyutlar düzeyinde ise; öfke kontrol yetersizliği ,827, güvenli davranış eksikliği ,612, heyecan arama davranışı ,469, dürtüsellik ,619, anksiyete ,827 ve depresyon ,788'dir.

\section{Veri Analizi}

Çalışmanın verileri bilgisayar ortamında değerlendirildi. Verilerin normal dağı̆ıma uygunluğu Kolmogorov Smirnov testi ile analiz edildi. Ölçeklerin araştırma örnekleminde tutarlılığı Cronbach $\alpha$ analizi ile değerlendirildi. Sosyodemografik özellikler ve madde kullanımına ilişkin veriler tanımlayıcı istatistiksel analizler; ortalama, standart sapma, ortanca, minimum ve maksimum değerler, yüzdelik ile değerlendirildi. DS tedbiri konan madde kullanıcılarında depresif belirti düzeyine göre bağımlılık şiddeti ve ayrımcılığa uğrama durumu ile bağımlılık şiddetinin karşılaştırımasında; iki bağımsı değişkenin karşılaştııımasında kullanılan nonparametrik test olan Mann-Whitney U testi kullanıldı. BDE ve BAPI-K ölçek puanlarının ilişkileri değerlendirilirken Spearman Korelasyon Analizi uygulandı. Tüm analizlerde güven aralığı 95 ve anlamlılık $\mathrm{p}<, 05$ olarak kabul edildi.

\section{Bulgular}

DS tedbiri konulan madde kullanıcıları $18-54$ yaş aralığında ve yaş ortalaması $28,93 \pm 6,96$ 'dır. Madde kullanıcılarının \%97'si erkek, \%40'ı ortaokul mezunu, \%59,1'i bekar olup, \%73,6'sının çocuğu yoktur ve \%10,3 ü yalnız yaşamaktadır. Madde kullanıcılarının \%59,7'si düzenli bir işte çalıştığını, \%68,8'i aylık gelirinin "orta seviyede" olduğunu ve \%73,9'u ceza evi yaşantısı bulunmadığını belirtti (Tablo 1).

Tablo 1. Sosyodemografik özelliklerin dağııımı

\begin{tabular}{|c|c|c|}
\hline \multicolumn{3}{|l|}{ Değişken } \\
\hline \multirow{2}{*}{$\begin{array}{l}\text { Yaş } \\
\text { Cinsiyet }\end{array}$} & \multicolumn{2}{|c|}{$\begin{array}{c}\text { Min-max: } 18-54 \\
\text { Ort } \pm \text { Ss: } \quad 28.93 \pm 6.96\end{array}$} \\
\hline & $\mathrm{n}$ & $\%$ \\
\hline Erkek & 320 & 97,00 \\
\hline Kadın & 10 & 3.00 \\
\hline \multicolumn{3}{|l|}{ Eğitim durumu } \\
\hline Okuryazar & 46 & 13,9 \\
\hline Ortaöğretim & 132 & 40,0 \\
\hline Lise & 100 & 30,3 \\
\hline Üniversite & 52 & 15,8 \\
\hline \multicolumn{3}{|l|}{ Medeni durum } \\
\hline Evli & 92 & 27,9 \\
\hline Bekar & 195 & 59,1 \\
\hline Boşanmış & 20 & 6,1 \\
\hline Evli eşinden ayrı & 3 & 9 \\
\hline Bekar, düzenli birlikteliği var & 20 & 6,1 \\
\hline \multicolumn{3}{|l|}{ Çocuk varlığı } \\
\hline Evet & 87 & 26,4 \\
\hline Hayır & 243 & 73,6 \\
\hline \multicolumn{3}{|l|}{ Çalışma durumu } \\
\hline İşsiz & 56 & 17,0 \\
\hline
\end{tabular}




\begin{tabular}{|c|c|c|}
\hline Düzensiz çalışma & 62 & 18,8 \\
\hline Düzenli çalışma & 197 & 59,7 \\
\hline Ev hanımı & 2 & 0,6 \\
\hline Diğer & 13 & 3,9 \\
\hline \multicolumn{3}{|l|}{ Aylık gelir düzeyi } \\
\hline Düşük & 86 & 26,1 \\
\hline Orta & 227 & 68,8 \\
\hline Yüksek & 17 & 5,2 \\
\hline \multicolumn{3}{|l|}{ Cezaevi yaşantısı } \\
\hline Yok & 244 & 73,9 \\
\hline Var & 86 & 26,1 \\
\hline Toplam & 330 & 100 \\
\hline
\end{tabular}

Min=minimum, max=maksimum, Ort=ortalama, Ss=Standart sapma

Çalışmada madde kullanıcılarının \%88,8'inin ailesinde madde kullanımının olmadığı, \%96,4'ünün çocukların yanında madde kullanmadığı bulundu. Madde kullanıcılarının \%53,9'unun madde kullanımı nedeniyle toplumda ayrımcılığa uğradığı, \%52,8'inin madde kullanmaya başladıktan sonra ruhsal sağlık sorunları yaşadığı belirlendi. Madde kullanıcılarının \%40,3'ü maddeye başlama nedenlerini "ortam", \%20,0'si "sorunlar" olarak belirtti ve \%28,5'i madde kullanımını sorun olarak görmediğini bildirdi (Tablo 2).

Tablo 2. Madde kullanıcılarının madde kullanımına ilişkin özellikleri

\begin{tabular}{|c|c|c|}
\hline Özellik & $\mathrm{n}$ & $\%$ \\
\hline \multicolumn{3}{|l|}{ Ailede madde kullanımı } \\
\hline Yok & 293 & 88,8 \\
\hline Var,1.derece akrabam & 24 & 7,3 \\
\hline Var,3.derece akrabam & 13 & 3,9 \\
\hline \multicolumn{3}{|l|}{ Çocukların yanında madde kullanımı } \\
\hline Kullanırım & 12 & 3,6 \\
\hline Kullanmam & 318 & 96,4 \\
\hline \multicolumn{3}{|l|}{ Ayrımcılığa uğrama durumu } \\
\hline Evet & 178 & 53,9 \\
\hline Hayır & 152 & 46,1 \\
\hline \multicolumn{3}{|l|}{ Maddeye başlama nedeni } \\
\hline Ortam & 133 & 40,3 \\
\hline Sorunlar & 66 & 20,0 \\
\hline Merak & 66 & 20,0 \\
\hline Keyif almak & 41 & 12,4 \\
\hline Diğer & 24 & 7,3 \\
\hline \multicolumn{3}{|c|}{ Maddeye başladıktan sonra yaşanan en önemli sorun } \\
\hline Sağlık Sorunları, Ruhsal Sorunlar & 174 & 52,8 \\
\hline Sorun Yaşamadım & 57 & 17,3 \\
\hline Aile Sorunları & 48 & 14,5 \\
\hline Yasal Sorunlar & 27 & 8,2 \\
\hline İş Sorunları, Maddi Sorunlar & 24 & 7,2 \\
\hline \multicolumn{3}{|c|}{$\begin{array}{l}\text { Madde kullanmak sizin için sorun mu, sorunsa ne kadar } \\
\text { zamandır? }\end{array}$} \\
\hline Sorun değil & 94 & 28,5 \\
\hline 1 yıldan az & 78 & 23,6 \\
\hline 1-2yıl & 61 & 18,5 \\
\hline 3-4yıl & 31 & 9,4 \\
\hline 5 yıldan fazla & 66 & 20,0 \\
\hline Toplam & 330 & 100 \\
\hline
\end{tabular}


Tablo 3. Madde kullanıcılarının BDE, BAPI ve BAPI-K ölçek puanları

\begin{tabular}{|l|c|c|c|}
\hline Ölçekler & Min-Max & Ortanca & Ort \pm Ss \\
\hline BDE & $0,00-50,00$ & 8,00 & $11,64 \pm 11,90$ \\
\hline BAPI-K Alt Boyutlar & & & \\
\hline Öfke & $3,00-11,00$ & 5,00 & $5,26 \pm 1,72$ \\
\hline Güvenli Davranış eksikliği & $5,00-28,00$ & 8,00 & $8,38 \pm 2,60$ \\
\hline Heyecan Arama Davranışı & $3,00-24,00$ & 5,00 & $4,99 \pm 1,83$ \\
\hline Dürtüsellik & $3,00-9,00$ & 5,00 & $4,99 \pm 1,40$ \\
\hline Depresyon & $4,00-12,00$ & 6,00 & $6,37 \pm 1,95$ \\
\hline Anksiyete & $3,00-9,00$ & 4,00 & $4,39 \pm 1,53$ \\
\hline BAPI Alt Boyutlar & & & \\
\hline Tanı & $6,00-28,00$ & 13,00 & $13,71 \pm 6,17$ \\
\hline Madde Kullanım Özelliği & $1,00-7,91$ & 3,27 & $3,48 \pm 1,32$ \\
\hline Yaşama Etki & $10,00-50,00$ & 24,00 & $25,14 \pm 10,63$ \\
\hline Şiddetli İstek & $4,00-20,00$ & 7,00 & $8,36 \pm 4,08$ \\
\hline Motivasyon & $3,00-15,00$ & 12,00 & $11,07 \pm 3,89$ \\
\hline BAPi-K Toplam/Şiddet & $4,50-21,50$ & 11,76 & $12,32 \pm 4,02$ \\
\hline
\end{tabular}

$\mathrm{BDE}=$ Beck Depresyon Envanteri, Min=minimum, max=maksimum, Ort=ortalama, $S \mathrm{~s}=$ Standart sapma, $\mathrm{BAP}=$ Bağımlılık Profil Indeksi BAPI-K= Bağımlılık Profil İndeksi Klinik Formu

Tablo 4. BDE kesme noktasına göre BAPI ve BAPI-K ölçek puanlarının karşılaştırılması

\begin{tabular}{|c|c|c|c|c|c|}
\hline \multirow[t]{2}{*}{ BAPI-K ve BAPI alt boyutlar } & \multicolumn{2}{|c|}{$\begin{array}{c}\text { Depresif Belirti Düzeyi } \\
\text { Düşük }\end{array}$} & \multicolumn{2}{|c|}{$\begin{array}{l}\text { jpresif Belirti Düzeyi } \\
\text { Yüksek }\end{array}$} & \multirow[b]{2}{*}{$Z$ ve $p$} \\
\hline & Ort $\pm S d$ & Median & Ort $\pm S d$ & Median & \\
\hline $\begin{array}{l}\text { BAPI-K Öfke Kontrol } \\
\text { Yetersizliği }\end{array}$ & $4,83 \pm 1,47$ & 5,00 & $6,45 \pm 1,79$ & 6,00 & $\begin{array}{l}16,04 \\
, 000^{*}\end{array}$ \\
\hline $\begin{array}{l}\text { BAPI-K Güvenli Davranış } \\
\text { Eksikliği }\end{array}$ & $7,65 \pm 2,34$ & 7,00 & $10,38 \pm 2,22$ & 10,00 & $\begin{array}{l}17,52 \\
, 000^{*}\end{array}$ \\
\hline $\begin{array}{l}\text { BAPI-K Heyecan Arama } \\
\text { Davranışı }\end{array}$ & $4,85 \pm 1,91$ & 5,00 & $5,38 \pm 1,53$ & 6,00 & $\begin{array}{l}13,08 \\
, 001^{*}\end{array}$ \\
\hline BAPI-K Dürtüsellik & $4,66 \pm 1,27$ & 5,00 & $5,87 \pm 1,39$ & 6,00 & $\begin{array}{l}15,46 \\
, 000^{*}\end{array}$ \\
\hline BAPI-K Depresyon & $5,68 \pm 1,50$ & 6,00 & $8,29 \pm 1,77$ & 8,00 & $\begin{array}{l}18,48 \\
, 000^{*}\end{array}$ \\
\hline BAPI-K Anksiyete & $3,90 \pm 1,12$ & 3,00 & $5,73 \pm 1,69$ & 6,00 & $\begin{array}{l}17,37 \\
, 000^{*}\end{array}$ \\
\hline $\begin{array}{l}\text { BAPI Bağımlılık Tanı } \\
\text { Kriterleri }\end{array}$ & $12,22 \pm 5,45$ & 11,00 & $17,80 \pm 6,19$ & 18,50 & $\begin{array}{l}15,90 \\
, 000^{*}\end{array}$ \\
\hline $\begin{array}{l}\text { BAPI Madde Kullanım } \\
\text { Özellikleri }\end{array}$ & $3,23 \pm 1,17$ & 2,72 & $4,18 \pm 1,47$ & 4,09 & $\begin{array}{l}14,99 \\
, 000^{*}\end{array}$ \\
\hline $\begin{array}{l}\text { BAPI Maddenin Yaşama } \\
\text { Etkisi }\end{array}$ & $22,48 \pm 9,41$ & 21,50 & $\begin{array}{c}32,45 \pm \\
10,42\end{array}$ & 34,00 & $\begin{array}{l}16,17 \\
, 000^{*}\end{array}$ \\
\hline $\begin{array}{l}\text { BAPI Maddeye Duyulan } \\
\text { Şiddetli İstek }\end{array}$ & $7,31 \pm 3,34$ & 6,00 & $11,27 \pm 4,52$ & 12,00 & $\begin{array}{l}15,98 \\
, 000^{*}\end{array}$ \\
\hline $\begin{array}{l}\text { BAPI Madde Bırakma } \\
\text { Motivasyonu }\end{array}$ & $10,79 \pm 3,96$ & 12,00 & $11,82 \pm 3,60$ & 13,00 & $\begin{array}{l}12,33 \\
, 026^{*}\end{array}$ \\
\hline BAPI Toplam/ Şiddet & $11,33 \pm 3,49$ & 10,92 & $15,06 \pm 4,13$ & 15,57 & $\begin{array}{l}16,05 \\
, 000^{*}\end{array}$ \\
\hline
\end{tabular}

BDE=Beck Depresyon Envanteri, BAPI=Bağımllık Profil Indeksi, BAPi-KBağımlılık Profil İndeksi Klinik Formu, z=Mann Whitney U

DS tedbiri konulan madde kullanıcılarının BAPi toplam /şiddet puan ortalaması 12,32 $\pm 4,02$ olup, ölçeğin kesme noktalarına göre; örneklemin \%51,5'inde bağımlılık şiddeti düşük, \%16,7'sinde orta ve \%31,8'inde yüksekti. BAPi-K alt boyutlarının puan ortalamalarına bakıldığında; öfke kontrol yetersizliği $5,26 \pm 1,72$,

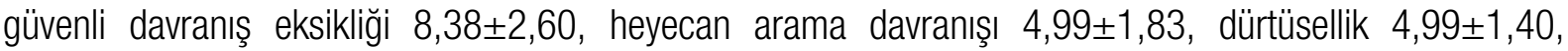




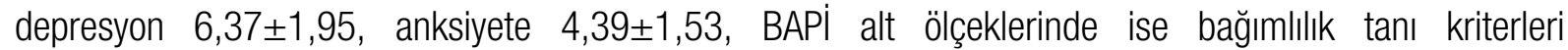
13,71 $\pm 6,17$, madde kullanım özelliği 3,48 $\pm 1,32$, madde kullanımının yaşama etkisi 25,14 $\pm 10,63$, madde kullanmaya duyulan şiddetli istek $8,36 \pm 4,08$ ve maddeyi bırakma motivasyonu puan ortalaması 11,07 $\pm 3,89$ olarak bulundu (Tablo 3).

DS tedbiri konulan madde kullanıcılarının ayrımclığa uğrama durumuna göre; BAPI-K ölçeği alt boyutlarından heyecan arama davranışı alt boyut puanları dışında tüm alt boyut puanları ve toplam bağımlılık şiddetinin, ayrımcılığa uğradığını ifade edenlerde etmeyenlere oranla istatistiksel olarak anlamlı düzeyde daha yüksek olduğu bulundu $(p<.05)$.

Madde kullanıcılarının BDE puanları ile; BAPI-K ölçeği alt boyutlarından güvenli davranış eksikliği ( $r=, 584$; $p<, 01)$, heyecan arama davranışı $(r=, 439 ; p<, 01)$, dürtüsellik $(r=, 531 ; p<, 01)$, depresyon $(r=, 548$; $p<, 01)$, anksiyete $(r=, 529 ; p<, 01)$, BAPI alt boyutlarında ise bağımlılık tanı kriterleri $(r=, 518 ; p<, 01)$, madde kullanım özelliği $(r=, 504 ; p<, 01)$, madde kullanımının yaşama etkisi $(r=, 559 ; p<, 01)$, maddeyi bırakma motivasyonu $(r=, 231 ; p<, 01)$ ve madde kullanmaya duyulan şiddetli istek $(r=, 558 ; p<, 01)$ puanları arasında pozitif yönde istatistiksel olarak anlamlı ilişkiler bulundu.

Çalışmamıza katılan, madde kullanıcılarında BDE kesme noktasına göre, bağımlılık şiddeti ve tüm alt boyutlarında alınan puanlar depresif belirti düzeyi yüksek olanlarda düşük olanlara göre istatistiksel olarak anlamlı ölçüde daha yüksekti $(p<, 05)$ (Tablo 4).

\section{Tartışma}

Madde kullanımı ile ilgili sorunlarda bağımlılık şiddetini belirlemek tedavi ve rehabilitasyon hizmetlerinin sunumuna kanıt oluşturabilir. Madde kullanımı nedeniyle bireylere DS tedbiri konması için madde bağımlısı olmalarının gerekmemesi, bir kez bile madde kullanmanın ceza almak ve DS sisteme dahil olmak için yeterli olması, bu grupta bağımlılık şiddetinin değerlendirilmesinin gerekli olduğunu düşündürmüştür. Bu çalışma; DS tedbiri bulunan madde kullanıcıları örnekleminde yapılmış olması ve depresif belirti düzeyine göre bağımlılık şiddetini ele alması açısından literatüre katkı sağlayabilir.

Çalışmamızda BAPI-K toplam/şiddet puan ortalaması $12,32 \pm 4,02$ 'dır ve DS tedbiri bulunan madde kullanıcılarının yaklaşık yarısında bağımlıık şiddeti orta ve yüksek düzeydedir. Daha önce bu grupta yapılan böyle bir çalışma olmadığı için, çalışma bulgumuz literatürde madde bağımlıları örnekleminde yapılan çalışmalarla tartışılmıştır. Bu çalışmalardan biri olan, Aksu ve ark (2020)'nın çalışmasında; eroin bağımlılığı olan hastaların alkol bağımlılarına göre daha düşük bağımlılık şiddetine sahip oldukları ancak daha fazla ruhsal belirti gösterdikleri bulunmuştur (7). Kassem (15) çalışmasında madde kullanan katılımcıların bağımlılık şiddetinin yüksek olduğunu belirlemiştir. BAPi kullanılarak yapılan bir başka çalışmada madde bağımlılığı olan hastaların \%43,8'nin bağımlılık şiddetinin yüksek olduğu bildirilmiştir (16). Bulgular çalışma bulgularımızla benzerlik göstermektedir. DS tedbiri konulan madde kullanıcılarının bağımlılık açısından riskli olduğu ve bağımlııı açısından değerlendirilmeleri gerektiği söylenebilir.

Çalışmamızda BAPI-K alt boyutlarında en yüksek puan madde kullanımının yaşama etkisi alt boyutundan alınmıştır. Madde kullanmaya başladıktan sonra katılımcıların \%52,8'i fiziksel ve ruhsal sağlık sorunları, $\% 14,5$ 'i aile sorunları ,\%8,2'si yasal sorunlar ve \%7,2'si iş ve maddi sorunlar yaşadıklarını, ayrıca $\% 53,9$ 'u da toplum tarafından ayrımcılığa uğradıklarını belirtmişlerdir. Ayrıca bağımlılık şiddetinin ayrımcılığa uğradığını ifade edenlerde etmeyenlere oranla istatistiksel olarak anlamlı düzeyde daha yüksek olduğu bulunmuştur. Benzer olarak, Aras (17)'ın çalışmasında madde bağımlılarının \%14,0'ünün madde kullanmaya başladıktan sonra sağlık sorunlarının arttığı (17), Aldemir ve arkadaşları (18) denetimli serbestlik tedbiri bulunan madde kullanıcılarının \%10,2'sinde fiziksel hastalık, \%31,8'inde ailesel sorunlar, \%34,1'inde iş/mesleki sorunlar olduğunu bildirmiştir. Yapılan bir çalışmada madde bağımlılı̆ı tanısı almış bireylerin \%84,5'inin "toplum tarafından dışlandığını" belirtikleri bulunmuştur (19). Çalışma bulguları birlikte düşünüldüğünde; madde kullanım sorunları olan bireylere sunulan sağlık hizmetlerinde kişisel yaşamının etkileniş biçiminin ve sorunların dikkate alınması, ayrımcılıkla mücadeleye odaklanılması ve çok boyutlu yaklaşımları kapsaması gerektiği söylenebilir. 
DS tedbiri bulunan madde kullanıcılarında depresif belirtiler ile bağımlılık şiddeti ve bağımlılıkla ilgili ruhsal sorunlar arasında istatiksel olarak anlamlı ilişkiler olduğu belirlenmiş̧tir. Bireylerin depresif belirti puanları artıkça BAPi-K bağımlılık tanı ölçütleri ve madde kullanım özellikleri, güvenli davranış eksikliği, depresyon, dürtüsellik, anksiyete, madde kullanımına duyulan şiddetli istek alt ölçek puanları yüksek düzeyde, heyacan arama davranışı orta düzeyde, maddeyi bırakma motivasyonu düşük düzeyde artmaktadır. Elde edilen bulgular doğrultusunda bireylerde depresif belirtilerin madde kullanımını her boyutuyla artırdığı, aynı zamanda maddeyi bırakma motivasyonunu da etkilediği söylenebilir. Benzer olarak; San ve arkadaşları (20) üniversite öğrencilerinde depresyon düzeyi ile madde bağımlı̆̆ğı arasında orta düzeyde pozitif yönde anlamlı bir ilişki olduğunu bulmuşlardır. McLaughlan ve Starkey (21)'e göre depresyon, anksiyete gibi duygudurum bozuklukları ile bağımlıık şiddeti arasında doğru orantılı bir ilişki bulunmaktadır. Hayatbakhsh ve ark (22) kenevir kullanan genç yetişkinlerde depresyon ve anksiyetenin madde kullanımı ile ilişkili olduğunu belirtmişlerdir. Pelissier ve 0'Neil (23), birden fazla madde kullanımıyla depresyon düzeyinin anlamlı şekilde arttığını bulmuşlardır. Koçhaş ve İlhan (24) madde kullanan askerlerde kullanmayanlara oranla depresyonun yüksek olduğunu bulmuştur. Madde kullanımında depresyonun varlığı farklı alanlarda da yaşamı etkileyebilmekte olup, Ciobanu ve ark (25) depresyon veya anksiyetesi olan madde kullanıcılarında yaşam kalitesinin azaldığını bulmuşlardır. Bizim çalışmamızın ve sözü edilen önceki çalışmaların sonuçları birlikte ele alındığında; depresif sorunlar ile bağımlılık şiddetinin ilişkili olduğu görülmektedir. Bu nedenle; madde kullanıcılarında depresyon açısından değerlendirme yapııması, depresyonun erken tanılanması ve tedavi edilebilmesinin önemli olduğu söylenebilir.

Araştırmaya katılan madde kullanıcılarının \%97'sinin erkek olması cinsiyete göre karşılaştırma yapılamaması bu araştırmanın ilk sınırılığıdır. Madde kullanıcıları DS polikliniklerine yasal zorunluluk nedeniyle geldikleri ve katılım motivasyonu düşük olduğu için bir örneklem seçme yöntemi kullanılamamış olması çalışmanın sınırlııklarındandır. Çalışmanın bir diğer sınırlıı̆̆ ise kullanılan madde türüne göre bağımlılık şiddetinin incelenememiş olmasıdır. İleriki çalışmalarda cinsiyet ve tercih maddesine göre depresyon ve bağımlılık şiddetinin incelenmesi önerilebilir.

Sonuç olarak; DS tedbiri konulan madde kullanıcılarının bağımlılık şiddeti yüksektir. Depresif belirti düzeyi bağımlılık şiddetini ve alt boyutta taranan sorunları artırmaktadır. Ayrımcılığa uğradığını ifade eden madde kullanıcılarında bağımlıık şiddeti daha yüksektir. Bu sonuçlar doğrultusunda; bu gruptaki bireylerin depresyon açısından yakından takip edilmesi, depresif durumlara erken müdahale edilmesi, madde kullanıcılarının yaşadığı ayrımcıı̆ga yönelik toplumsal düzeyde farkındalık çalışmaları yapııması önerilebilir. Bu alanda daha çok kanıta gereksinim olmasından dolayı, cinsiyet ve tercih maddesine göre depresyon ve bağımlılık şiddetini inceleyen yeni çalışmalar yapııması önerilebilir. Ayrıca depresyona neden olabilecek birçok sosyal, tıbbi ya da ekonomik durumun olduğu düşünüldüğünde depresyonu değerlendirmek için daha farkı psikometrik araçların kullanılması ileriki çalışmalar için önerilebilir.

\section{Kaynaklar}

1. Kamer VK. Madde bağımlılarınım rehabilitasyonunda yeni dönem denetimli serbestlik. Türkiye Barolar Birliği Dergisi 2008; 79: 275-308.

2. Toker Uğurlu T, Tekkanat Ç, Koç $H$, Ateşci FF. Alkol ve madde kullanım bozukluğu olan bireylerde suç davranıșının retrospektif incelemesi. Pamukkale Tıp Dergisi 2020; 13: 739-747.

3. Havaçeliği Atlam D, Şaşman Kaylı D. Bağımlılıkta riskli bir durum:suç davranışı. Yüncü Z (Editör). Ergen Bağımlıı̆̆ı. 1. Baskı. Ankara: Türkiye Klinikleri 2019: 11-7.

4. Grahn R, Padyap M, Hall T, Lundgren L. The Associations between risky psychosocial environment, substance addiction severity and imprisonment: a Swedish Registry study. Subst Use Misuse 2020; 55: 697-706.

5. Derin M, Tapan MG. Madde bağımlığı ve sosyal dışlanma. Tıbbi Sosyal Hizmet Dergisi 2017; 10: 26-36.

6. Ögel K, Karadağ F, Evren C, Gürol DT. Bağımlııık Profil İndeksi (BAPI) Uygulama Rehberi Yeniden Yayınları. İstanbul, 2012.

7. Aksu MH, Şahiner SY, Şahiner IV et al. Relationship between somatization and psychiatric symptoms, especially anxiety, depression, alexithymia, and severity of addiction in male patients with alcohol and heroin addiction. Dusunen Adam 2020; 33: 120-129. 
8. Mohamed II, Khalifa Ahmad HE, Hassaan SH, Hassaan SM. Assessment of anxiety and depression among substance use disorder patients: a case-control study. Middle East Curr Psychiatry 2020; 27: 22-30.

9. Öner H, Tamam, L, Levent BA, Öner S. Alkol bağımlılı̆ı olan yatan hastalarda Eksen I ve Eksen II eş tanılarının değerlendirilmesi. Klin Psikofarmakol Bulteni 2002; 12: 14-22.

10. Najt P, Fusar-Poli P, Brambilla P. Co-occurring mental and substance abuse disorders: a review on the potential predictors and clinical outcomes. Psychiatry Res 2011; 186: 159-164.

11. Blum J, Gerber H, Gerhard U, et al. Acute effects of heroin on emotions in heroin-dependent patients. Am J Addict 2013; 22: 598-604.

12. Lee KH, Yen C F. The relationships between depression, neuroticism, and attitudes (nda model) in heroin abusers in Taiwan. Am J Addict 2018; 27: 139-143.

13. Hisli N. Beck Depresyon Envanterinin üniversite öğrencileri için geçerliliği, güvenirliği. Türk Psikoloji Dergisi 1989; 7: 3-13.

14. Ögel K, Koç $C$, Başabak A, et al. Bağımlılık profil indeksi klinik formunun (BAPi-K) geliştirilmesi: Geçerlik ve güvenilirlik çalışması. Bağımlıık Dergisi 2015; 16: 57-69.

15. Kassem N. Tercih maddesi ve bağımlılık șiddetine bakılarak bağımlılarda yașama son verme düșüncesi yoğunluğunun araştıııması. Cyprus Turkish Journal of Psychiatry \& Psychology 2019; 1(Özel Sayı.1): 36-39.

16. Orum $\mathrm{MH}$, Kuştepe $\mathrm{A}$, Kara $\mathrm{MZ}$, et al. Addiction profiles of patients with substance dependency living in Adıyaman province. Medicine Science 2018; 7: 369-372.

17. Aras G. Erkek Alkol ve Madde Bağımlılarının Kaygı Depresyon ve Hastalık Algısı Yönünden Karşılaştıııması. Yüksek Lisans Tezi, Ankara: Gazi Üniversitesi Sağlık Bilimleri Enstitüsü Hemşirelik Anabilim Dall, 2015.

18. Aldemir E, Berk G, Coşkunol H. Denetimli serbestlik bağımlılık programının tedavi motivasyonu, ayıklık ve yaşam kalitesi üzerine etkileri: motivasyonel ve bireysel görüşme ile karşılaştırmalı bir çalışma. Noro Psikiyatr Ars 2018; 55: 261-270.

19. Tektaş Soy I, Kocataş S. Madde bağımlıı̆ı tanısı almış bireylerde benlik saygısı ve sosyal dışlanma algıları arasındaki ilișki. Ege Üniversitesi Hemșirelik Fakültesi Dergisi 2020; 36: 73-86.

20. San A, Erensoy H, Aytaç HM, Berkol TD. Üniversite öğrencilerinde depresyon düzeylerinin, madde kullanımları ve aile tutumları ile ilişkisi. Bağımlılık Dergisi 2020; 21: 1-12.

21. McLaughlan AD, Starkey NJ. The classification of substance and behavioural addictions: a preliminary investigation. NZ J Psychol 2012; 41: 7-17.

22. Hayatbakhsh M, Najman JM, Jamrozik K, et al. Cannabis and anxiety and depression in young adults: A large prospective study. J Am Acad Child Adolesc Psychiatry 2007; 46: 408-417.

23. Pelissier BMM, O'Neil JA. Antisocial personality and depression among incarcerated drug treatment participants. J Subst Abus 2000; 11: 379-393.

24. Koçhaş K, IIIhan T. Erbaş/Erlerin ebeveyne bağlanma stilleri, depresyon düzeyleri ve stresle başa çıkma stillerinin madde kullanımı açısından incelenmesi. Addicta: The Turkish Journal on Addictions 2015; 2: 61-109.

25. Ciobanu J, Di Patrizio P, Baumann C, et al. Relationships between coping, anxiety, depression and healthrelated quality of life in outpatients with substance use disorders: results of the SUBUSQOL study. Psychol Health Med 2020; 25: 179-189. 